\title{
Da'wah Strategy as an Effort to Preserve the Environment
}

Ibnu Hajar $\mathrm{S}^{1}$, Suharto Suharto ${ }^{2}$, Andi Muhammad Saleh Alwi ${ }^{3}$, Nurfatimah Nurfatimah ${ }^{4}$, Jusmawati Jusmawati ${ }^{5}$

${ }^{1}$ Sekolah Tinggi Agama Islam (STAI) Darul Dakwah Wal-Irsyad (DDI) Kota Makassar, Indonesia

Email: dewaibnuhajar@gmail.com

${ }^{2}$ Institut Agama Islam Negeri (IAIN) Palu, Indonesia

Email: suharto@iainpalu.ac.id

${ }^{3}$ Sekolah Tinggi Agama Islam (STAI) Darul Dakwah Wal-Irsyad (DDI) Kota Makassar,

Indonesia

Email: aleahm4d@gmail.com

${ }^{4}$ Universitas Islam Negeri (UIN) Alauddin Makassar, Indonesia

Email: nurfatimah.nurfatimah91@gmail.com

${ }^{5}$ Universitas Mega Rezky, Makassar, Indonesia

Email: jcjusmawati030490@gmail.com

\begin{abstract}
.
Environmental pollution is a common problem that is important to solve because it involves safety, health, and human survival. Anyone can play a role and take responsibility for solving this problem. Strategies and concrete steps are needed to prevent environmental damage that is getting worse. Da'wah is one way to preserve the environment. For this goal, da'wah needs qualified preachers who have broad minds, insights, and knowledge. Preserving the environment and minimizing environmental damage also needs maximum efforts in the form of increasing public awareness by creating synergy between them and their initiatives.
\end{abstract}

Keywords: Strategy; Da'wah; Environment 